\title{
The Sea of Okhotsk crust from deep seismic sounding data
}

\author{
V. B. Piip \\ Moscow State University, Moscow
}

\author{
A. G. Rodnikov \\ Geophysical Center, Russian Academy of Sciences, Moscow
}

\begin{abstract}
The crustal structure of the Sea of Okhotsk was investigated by way of reinterpreting the data obtained along 22 deep seismic sounding (DSS) profiles. Eight profiles traversed the Sea of Okhotsk. These seismic surveys were performed during the International Geophysical Year in 1958-1959 by the researchers from the Institute of the Physics of the Earth, USSR Academy of Sciences. Seven profiles were surveyed in 1963-1964 near the shores of Sakhalin Island by geophysicists from the Institute of the Physics of the Earth (USSR Academy of Sciences) and from the Sakhalin Multidisciplinary Research Institute. The new interpretation of the seismic data confirmed the earlier ideas of the reduced crustal thickness in the deep-sea basins of the Sea of Okhotsk, such as, the Kuril Basin, the Deryugin and Tinro basins, the sedimentary trough of the Tatar Strait, where the Moho surface showed low boundary velocities of seismic waves, not higher than 7.6-7.8 $\mathrm{km} \mathrm{s}^{-1}$. It appears that the sedimentary basins of the Sea of Okhotsk reside above asthenospheric diapirs including magma chambers. A system of rifts and spreading centers was mapped in the northern and central parts of the Sea of Okhotsk, in the Tatar Strait, and in the Kuril Basin. Paleosubduction zones that had been active during the late Cretaceous and Early Paleogene time and are marked by ophiolite belts at the present time have been traced in the earth crust near the eastern shores of Sakhalin. Remnants of paleosubduction zones were mapped using seismic data in the Sea of Okhotsk along the Okhotsk-Chukotka volcanic belt, which seem to be the fragments of a lithospheric plate that had been going down under the active continental margin in Mesozoic time.
\end{abstract}

\section{Introduction}

The crustal structure of the Sea of Okhotsk was investigated by way of reinterpreting the data obtained along 15 deep seismic sounding (DSS) profiles. Eight profiles, namely, $1 \mathrm{M}, 6 \mathrm{M}, 9 \mathrm{M}, 10 \mathrm{M}, 11 \mathrm{M}, 12 \mathrm{M}, 13 \mathrm{M}$, and $14 \mathrm{M}$, traversed the

Copyright 2004 by the Russian Journal of Earth Sciences.

Paper number TJE03140.

ISSN: $1681-1208$ (online)

The online version of this paper was published 8 January 2004. URL: http://rjes.wdcb.ru/v05/tje03140/tje03140.htm
Sea of Okhotsk. These seismic surveys were performed during the International Geophysical Year in 1958-1959 by the researchers from the Institute of the Physics of the Earth, USSR Academy of Sciences, at the highest level of that time. Seven profiles, namely, 18, 19, 20, 27, 28, 29, and 30, were surveyed in 1963-1964 near the shores of Sakhalin I. by geophysicists from the Institute of the Physics of the Earth (USSR Academy of Sciences) and from the Sakhalin Multidisciplinary Research Institute. The location of the profile lines is shown in Figure 1. The profiles varied from 250 to $750 \mathrm{~km}$ in length. The interpretation of the data, performed at that time, served as a basis for the further studies of the geologic structure of the region. The travel-time curves of the first-arriving waves plotted from these pro- 


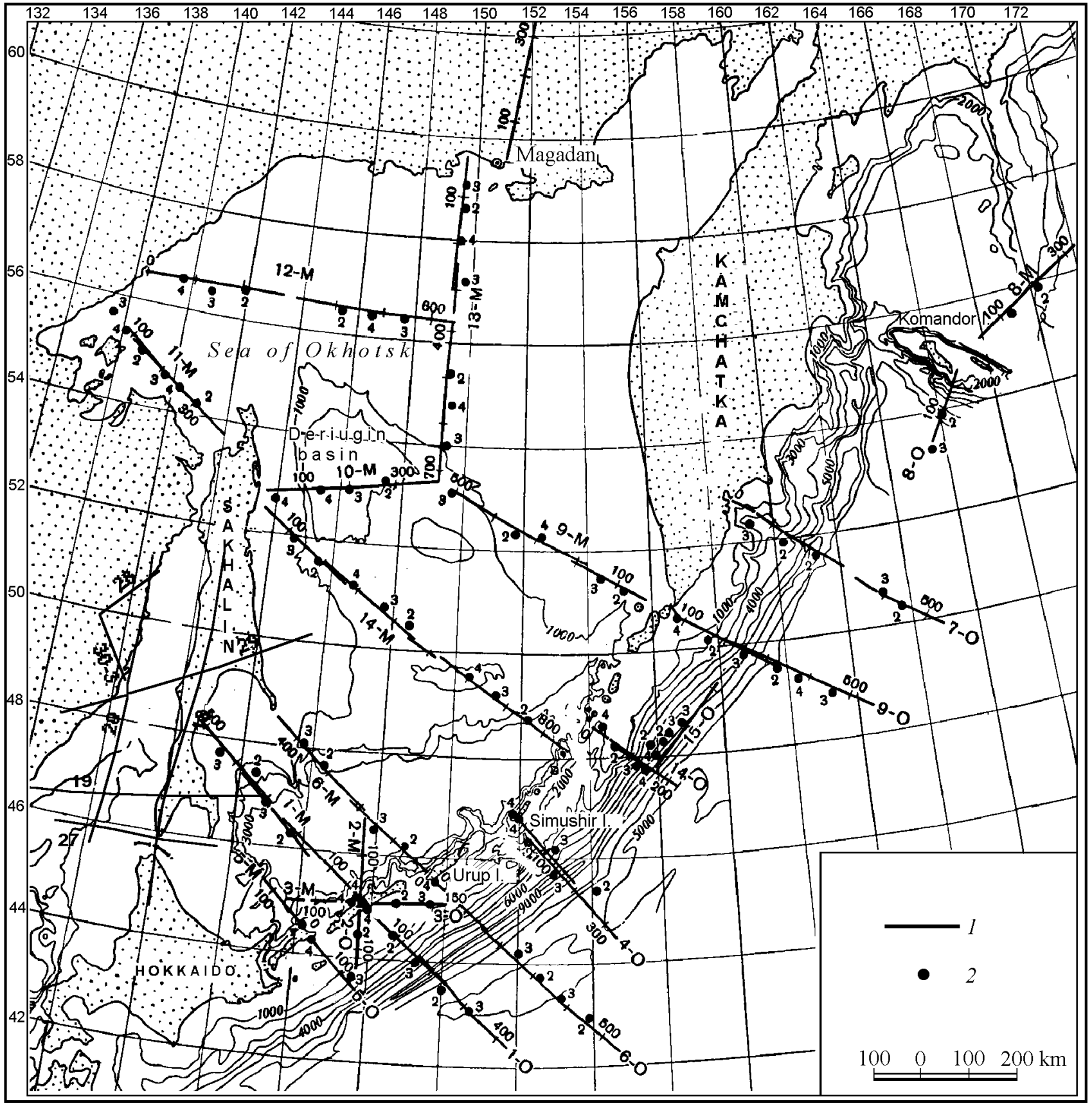

Figure 1. Map of location of profiles. 1 is lines of the profiles, 2 is location of seismic stations. (From Galperin and Kosminskaya, [1964], revised).

files were published in the papers of that time [Galperin and Kosminskaya, 1964; Zverev and Tulina, 1971]. We digitized these travel-time data and interpreted them using moderntechnology computer means, namely, a method of homogeneous functions [Piip, 1991, 1997, 2001]. Detailed seismic sections were obtained to depths of $30-60 \mathrm{~km}$. On the av- erage, the new seismic sections agreed with the old ones in terms of the main boundaries and velocity values. The resulting seismic sections and velocity maps showed, for the first time, the blocks of down-going plates, the remnants of the subduction zones, rifts in the deep basins, and a system of gently dipping and steep faults. 

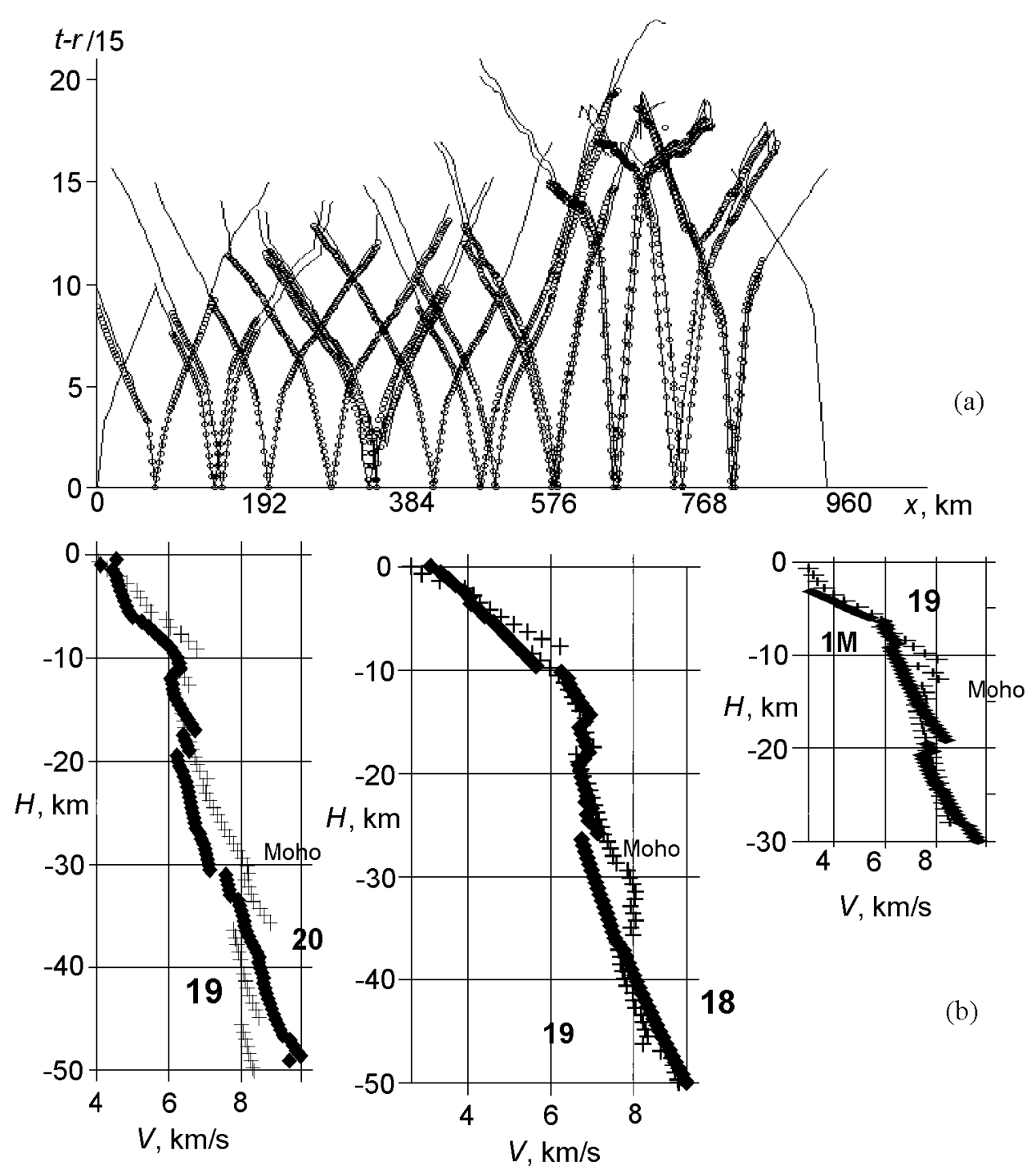

18

(b)

Figure 2. a - Comparison of observed travel time curves (thin lines) with synthetic ones (circles) for 1O-1M profiles; $\mathrm{b}$ - Vertical velocity functions in points of intersection of 19 profile (crosses) with others profiles, at the left with 20 profile, in middle with 18 profile and on the right with $1 \mathrm{M}$ profile.

\section{Data Interpretation}

The data were interpreted using a method of homogeneous functions. This method of interpretation and a "GODOGRAF" computer program had been developed at the Moscow State University [Piip, 1991, 2001]. This method is based on the local approximation of real velocity fields using homogeneous two-coordinate functions. This approach allows one to derive automatically, using the travel-time curves of the first waves, the 2-D heterogeneous velocity fields, determined at the nodes of a rectilinear 250 by 100 network. The cross-sections are displayed as a field of velocity contour lines with a constant interval (usually $0.1-0.2 \mathrm{~km} \mathrm{~s}^{-1}$ ). Seismic boundaries and faults are clearly seen in the velocity field to be traced by the interpreter.
This representation of cross-sections allows one to plot horizontal velocity maps at various depths, where several seismic profiles area available. This method of interpretation does not require any initially assumed model and, hence, the resulting seismic sections can be regarded as objective ones. We verified their reliability (1) by the coincidence of the vertical velocity curves at the points of the profile intersections (Figure 2b), (2) by the solution of a direct problem (the rms deviation of the observed travel times from the calculated ones was $0.3-0.4$ seconds) (Figure $2 \mathrm{a}$ ), (3) by the agreement between the depths of the main discontinuity surfaces using the results of the previous and new interpretation.

In this work we used the following designations. In the case of the continental crust we used $V=6.0-7 \mathrm{~km} \mathrm{~s}^{-1}$ for the upper crust, and $V=7.0-8.0 \mathrm{~km} \mathrm{~s}^{-1}$ for the lower crust. The first, second, and third layers of the crust were labelled 


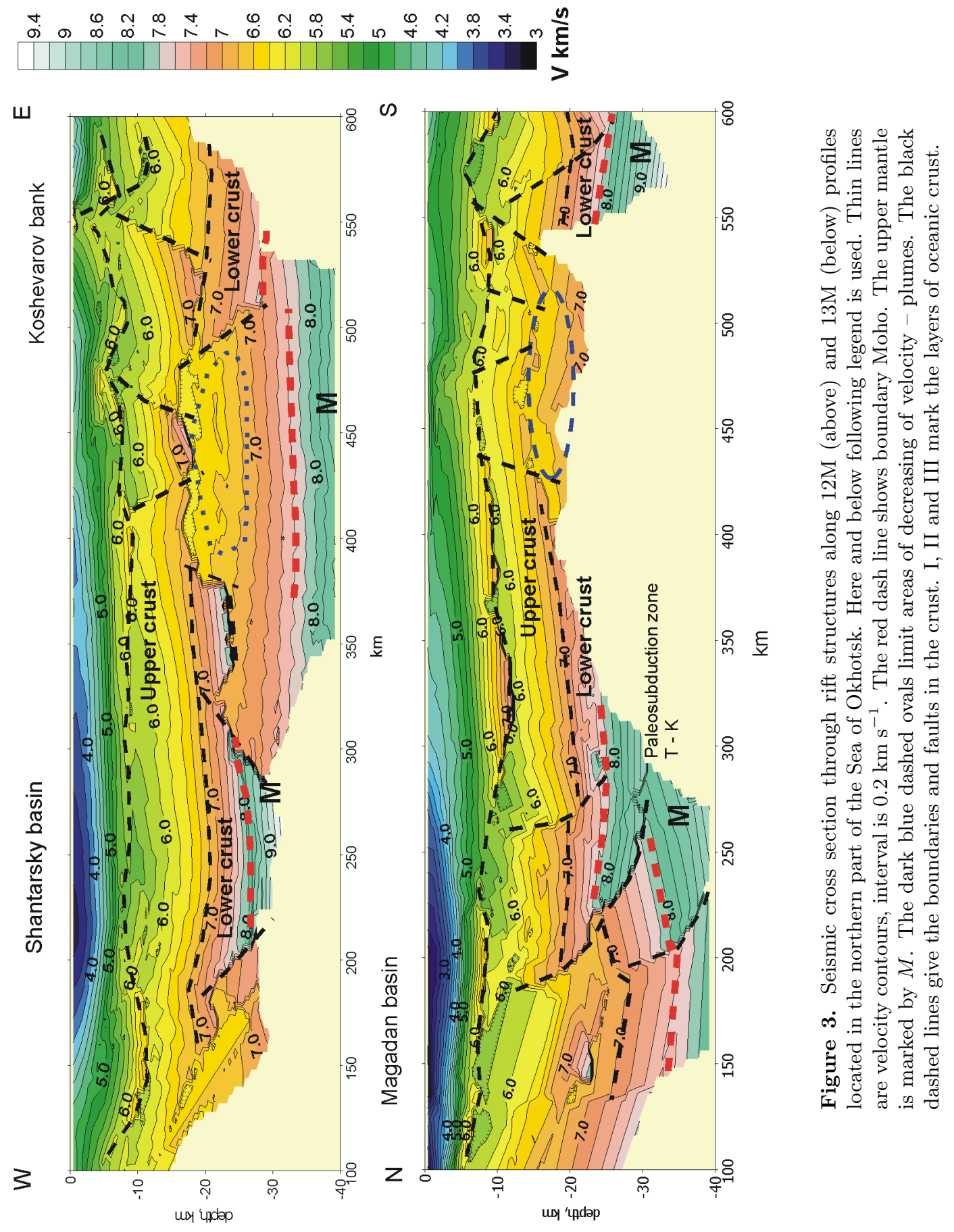


as I, II, and III. The upper mantle was designated by an $M$ symbol. The thin lines are the velocity contours obtained using a computer, the dash lines show boundaries and the faults. The explanation of the colored lines are given in the figure captions.

\section{The Northern Part of the Sea of Okhotsk}

The seismic sections along the $12 \mathrm{M}$ and $13 \mathrm{M}$ lines in the northern part of the Sea of Okhotsk are shown in Figure 3. The earth crust consists of two layers there. The central part of this segment of the Sea of Okhotsk (west of Kamchatka) includes a clearly expressed rift with a break in the $M$ discontinuity (the $M$ depth changes from 25 to $35 \mathrm{~km}$ ) and with an abrupt velocity decline in the lower crust. The upper crust is broken by faults. The sedimentary layer shows some velocity growth. In the vicinity of the continent the depth of the $M$ surface is $25 \mathrm{~km}$; the lower crust shows a high velocity gradient (oceanic crust?) and descends stepwise under the continent. It appears that the seismic data recorded the remnants of some ancient subduction zones which had been active, as follows from the data reported in [Abramovich et al., 2001; Konstantinovskaya, 2001], in the Mesozoic era, when the oceanic crust had been subsiding under the OkhotskChukotka volcanic belt which had been an island arc at that time.

\section{The Central Part of the Sea of Okhotsk}

Two profiles, 9M-9O and 14M, were surveyed across central part of the Sea of Okhotsk, from Sakhalin I. and the Deryugin Basin to the Kuril-Kamchatka Island Arc (Figure 4). In the central part of the Sea of Okhotsk the depth of the Moho surface is greater than $30 \mathrm{~km}$, which suggests, along with the dredging data [Krasnyi, 2002], the development of the continental crust. The crust consists of two, upper and lower, layers. The crust is broken by faults and rifts. The Moho surface is uneven, and the Upper Mantle shows regions with seismic velocities, as high as $9 \mathrm{~km} \mathrm{~s}^{-1}$. In the vicinity of the Deryugin Basin, the $9 \mathrm{M}-9 \mathrm{O}$ profile showed a growth of the crustal thickness at the expense of the sedimentary layer. As profile 14M approached the Sakhalin Island, where ophiolites have been traced along the eastern coast of the island, the Sea of Okhotsk lithosphere was found to contain the remnants of the ancient zones of subduction which had taken place in the Late Cretaceous-Early Paleogene time. The structural features interpreted as relict subduction zones are present in the Sea of Okhotsk and under the Kamchatka Peninsula. These structural features have roughly equal sizes and some peculiarities. Examples of the latter are the development of listric faults (roughly 15?), extending from the sedimentary layer into the upper mantle, the faults observed in the Moho surface, thickness variations in the upper crustal layer, and the presence of high-velocity crustal blocks.

\section{North Sakhalin and Deryugin Basin}

North Sakhalin includes the North Sakhalin sedimentary basin. Its basement is composed of Triassic-Early Cretaceous volcanogenic siliceous and occasional Late Cretaceous volcanogenic rocks. Its depth ranges from 5.0 to $12 \mathrm{~km}$ in some downthrown blocks and from 1.5 to $3 \mathrm{~km}$ in the internal uplifts. The sedimentary basin is filled with Cenozoic deposits which had accumulated in the lower part during the rift stage and later during the post-rift stage of the basin evolution. The structure of the Sakhalin crust was studied only using the data collected along the $11 \mathrm{M}$ profile, extending from the Shantar Ils. to North Sakhalin (Figure 5), the data collected along profiles 18 and 20, extending along the western and eastern shores of Sakhalin (Figure 6). This region is underlain by continental crust, 30-40 km thick. The heat flow values are intermediate. The asthenosphere was recorded by electromagnetic data to be at a depth of about $70 \mathrm{~km}$ [Rodnikov et al., 1996]. This basin is located above an ancient subduction zone which is represented now by the Shmidt Rise separating it from the Deryugin Basin, and composed of ophiolites. It is supposed that the ophiolites mark the position of an old seismic focal zone, that is, of the mesozoic zone of the subduction of the Sea of Okhotsk oceanic crust under Sakhalin [Grannik, 1999]. This supposition has been confirmed by the Late Cretaceous-Paleogene volcanic arc discovered in the eastern areas of Sakhalin by V. M. Grannik and found by him to be composed of the fragments of volcanic islands, inter-arc and forearc basins, overlying in an allochthonous manner the marginal-sea rocks in the eastern areas of central and North Sakhalin [Grannik, 1999]. The volcanic arc is composed of andesite, dacite, rhyolite and their calc-alkalic tuffs. In Late Mesozoic time a back-arc trough composed of terrigenous, siliceous, and carbonate rocks, with occasional interlayers of calc-alkalic volcanic rocks, had existed in North Sakhalin.

The Deryugin Basin is located east of the old subduction zone (Figure 5). Its sedimentary cover consists of Cenozoic mainly deep-sea terrigenous and siliceousterrigenous deposits up to $12 \mathrm{~km}$ thick. Its recent tectonic activity is accentuated by heat-flow values as high as $200 \mathrm{~mW} \mathrm{~m}^{-1}$ and by seismic events restricted mainly to the western side of the Deryugin Basin, where an old seismic focal zone has been located. The thick sedimentary cover of the basin rests on the uneven surface of the acoustic basement with seismic velocities of $6.2-6.4 \mathrm{~km} \mathrm{~s}^{-1}$. The Moho surface showed low velocities $\left(7.6 \mathrm{~km} \mathrm{~s}^{-1}\right)$ [Piip, 1997]. The insignificant thickness of the basement $(<10 \mathrm{~km})$ is believed to owe its origin to the processes of extension and subsequent subsidence. The basement is supposed to be composed of Mesozoic oceanic volcanogenic-siliceous and argillaceous deposits which are exposed in Sakhalin and West Kamchatka [Rodnikov et al., 1996]. The seismic profiles available show the subduction zone as a series of en-echelon arranged blocks of elevated-velocity crustal and upper mantle rocks. The Deryugin Basin is distinguished by elevated heat-flow values, a thin crust, and seismic and hydrothermal activity. The new interpretation of seismic data suggests a rift structure at the base of the basin (Figure 5). The basin is located 


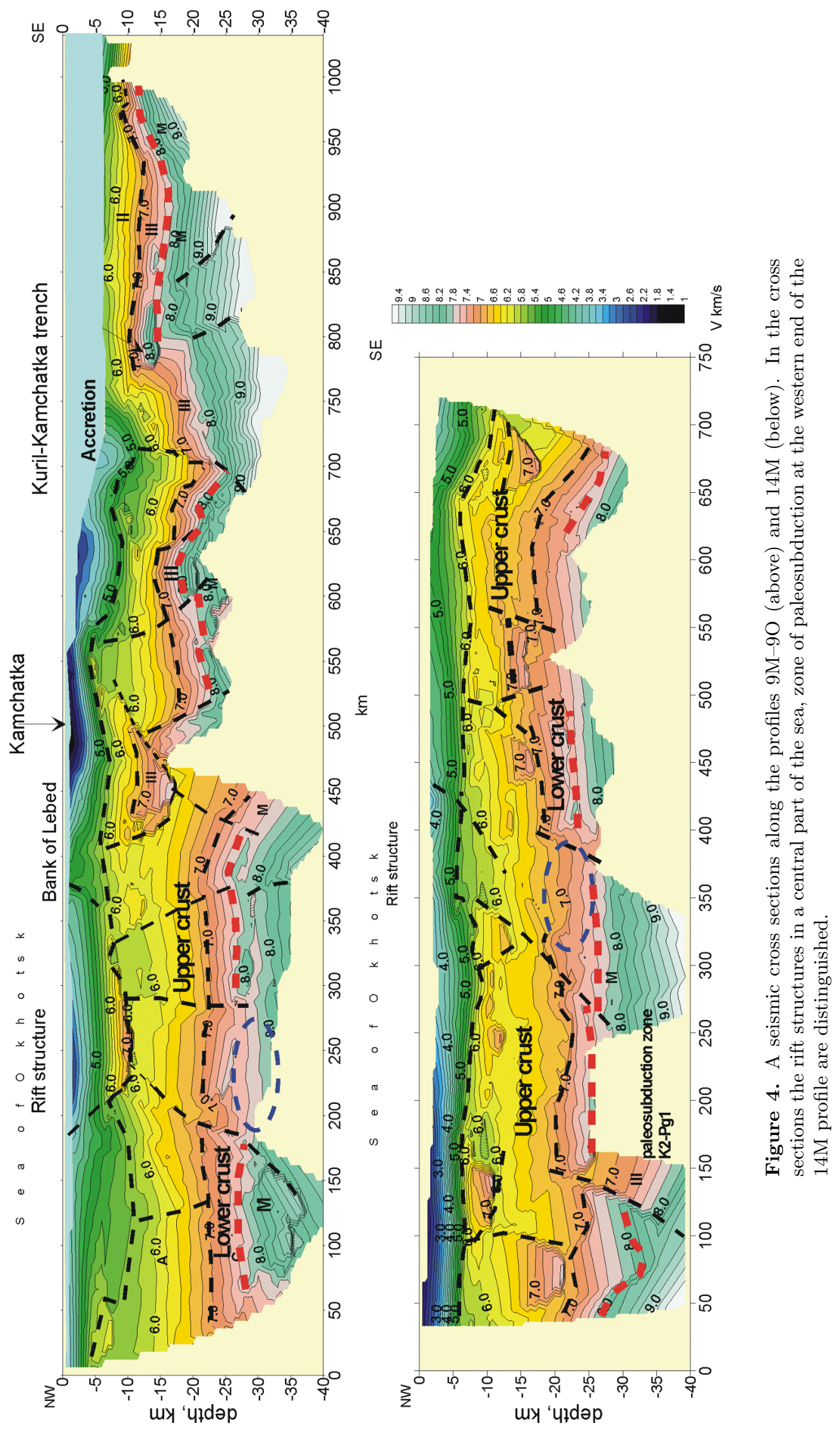




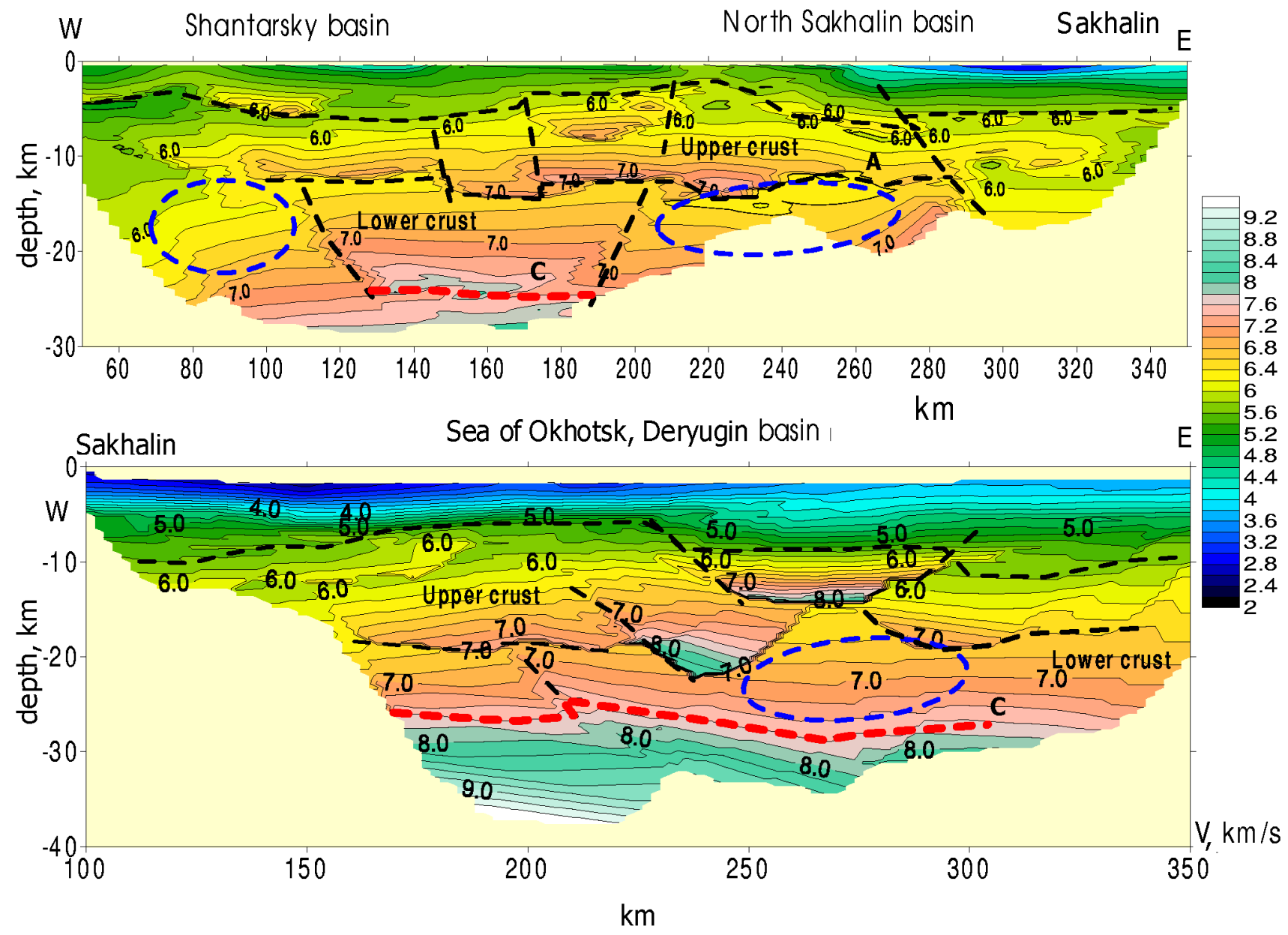

Figure 5. Seismic cross sections of earth crust along the $11 \mathrm{M}$ (above) and 10M (below) profiles. Thin lines are velocity contours, interval is $0.2 \mathrm{~km} \mathrm{~s}^{-1}$. The red dashed line shows the Moxo boundary. Dark blue dotted line limits areas of decreasing of velocity. The boundaries and the faults in the crust are shown by black dash lines.

above a mantle hot plume produced by a partial-melting asthenospheric diapir, discovered in the upper mantle at a depth of $25 \mathrm{~km}$ [Rodnikov et al., 2001a, 2001b]. The western side of the basin is bounded by an ophiolite belt of ultrabasic igneous rocks, which seems to mark an old (Cretaceous-Paleogene) earthquake focal zone between the Deryugin Basin and East Sakhalin, which had been an island arc with andesite igneous activity at that time (100-60 million years ago).

\section{Tatar Strait}

In terms of its crustal structure the Tatar Strait is a rift filled with Late Cretaceous-Cenozoic sandy and argillaceous deposits up to $12 \mathrm{~km}$ thick. It is bounded by the Sikhote-Alin and West Sakhalin mountains in the west and east, respec- tively. The basement is composed of Triassic-Early Cretaceous and occasional Late Cretaceous terrigenous sandy and clayey and volcanic siliceous rocks. Its depth ranges from 5 to $12 \mathrm{~km}$. The four seismic sections obtained along the profiles crossing the Tatar Strait showed many features in common (Figures 7 and 8). All profiles showed a rift in the central part of the Tatar Strait, which had not been recorded by the previous seismic profiles. The rift is distinguished by lower velocities in the lower crust and a series of faults dissecting the crust. The modern seismic activity is proved by high heat flow values, magmatic activity, and seismic events. As a result, the crust has a low thickness $(25 \mathrm{~km})$, as compared with the surrounding regions, the seismic velocities along the Moho discontinuity being $7.4-7.6 \mathrm{~km} \mathrm{~s}^{-1}$. The faults recorded by deep seismic soundings (DSS) have been confirmed by geological evidence. A good example is the West Sakhalin fault, bordering the Tatar Strait in the 


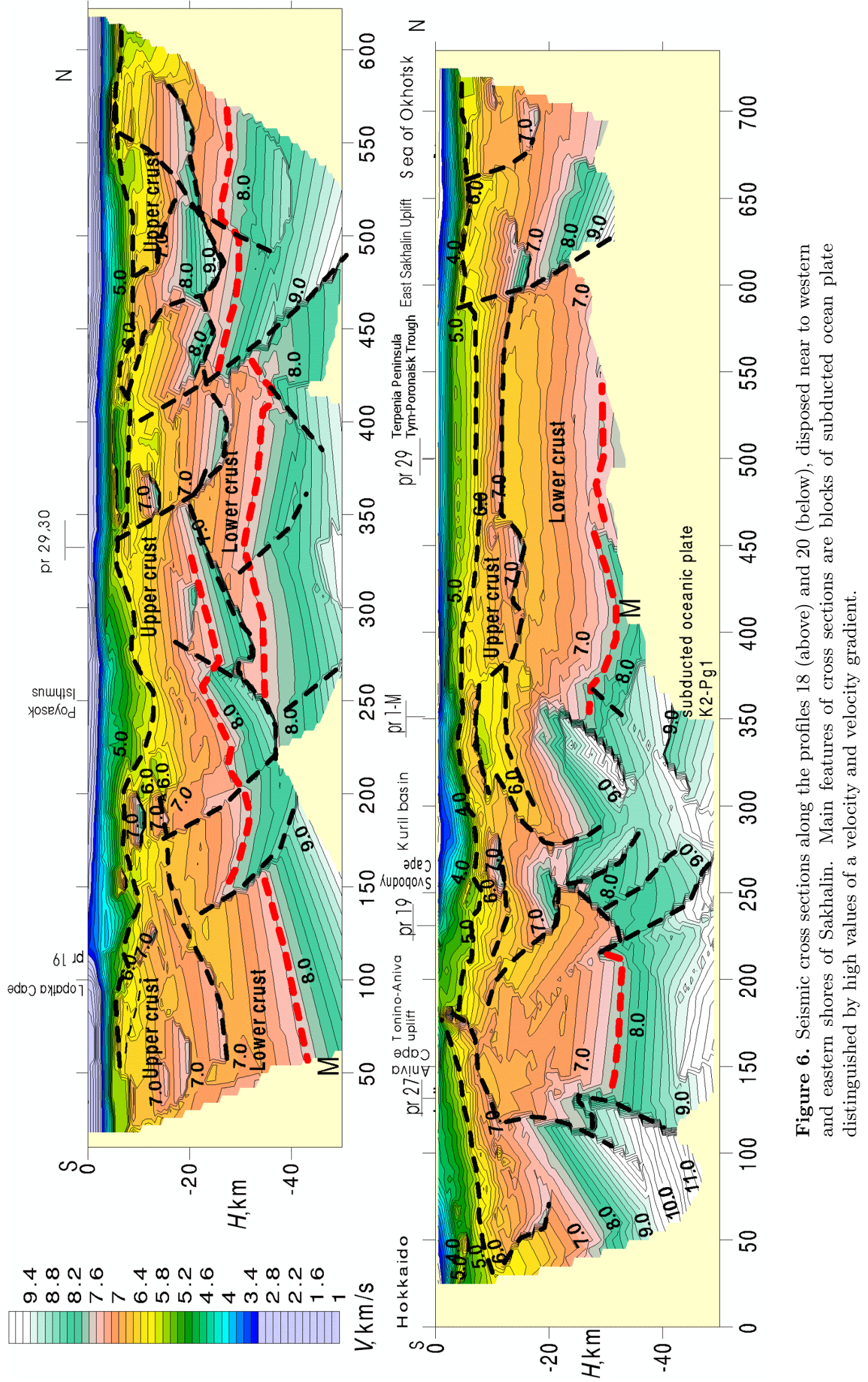



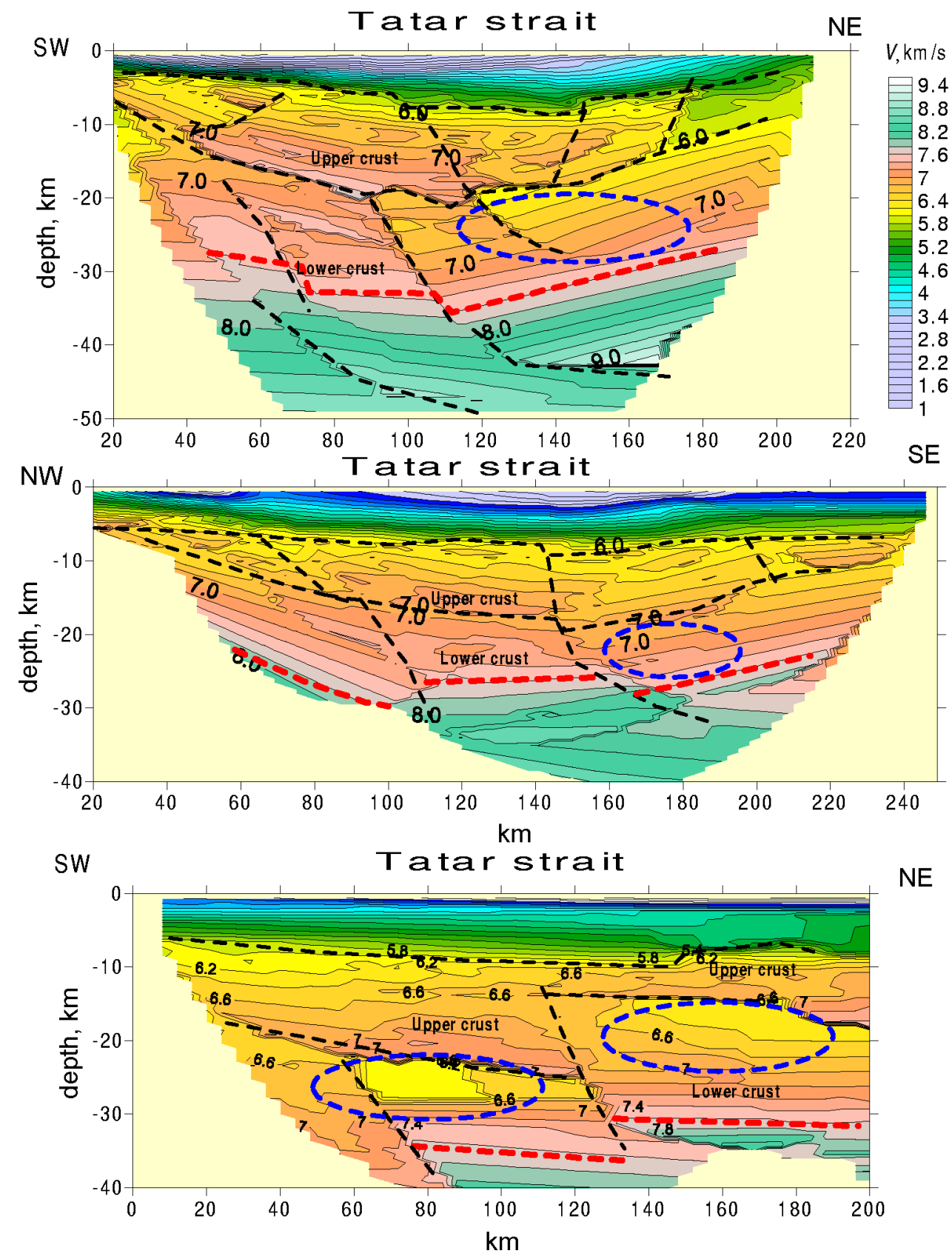

NE

Figure 7. Seismic cross sections along 28 (above), 30-W in (middle) and 29-W (below) profiles in Tatar strait. The rift structure is distinguished in the crust in all cross sections.

east, where the Cenozoic deposits are dipping steeply $\left(50^{\circ}-\right.$ $80^{\circ}$ ) to the west and are highly disturbed by normal and reverse faults. The movements along the faults vary from hundreds of meters to $4-5 \mathrm{~km}$. Restricted to the fault zone are Early and Late Miocene and Pliocene volcanic centers. The faults show a high seismic activity and fluid penetration [Rodnikov et al., 1996]. The calculation of deep tem- peratures revealed that the sedimentary trough is underlain by a hot asthenospheric diapir which had been responsible for crustal breaks, the formation of rifts at the base of the trough, magmatic activity, and the heating of the sedimentary layer. The asthenospheric diapir might have served as an additional source of hydrocarbons and fluids responsible for high hydrothermal activity [Rodnikov et al., 2001b]. 


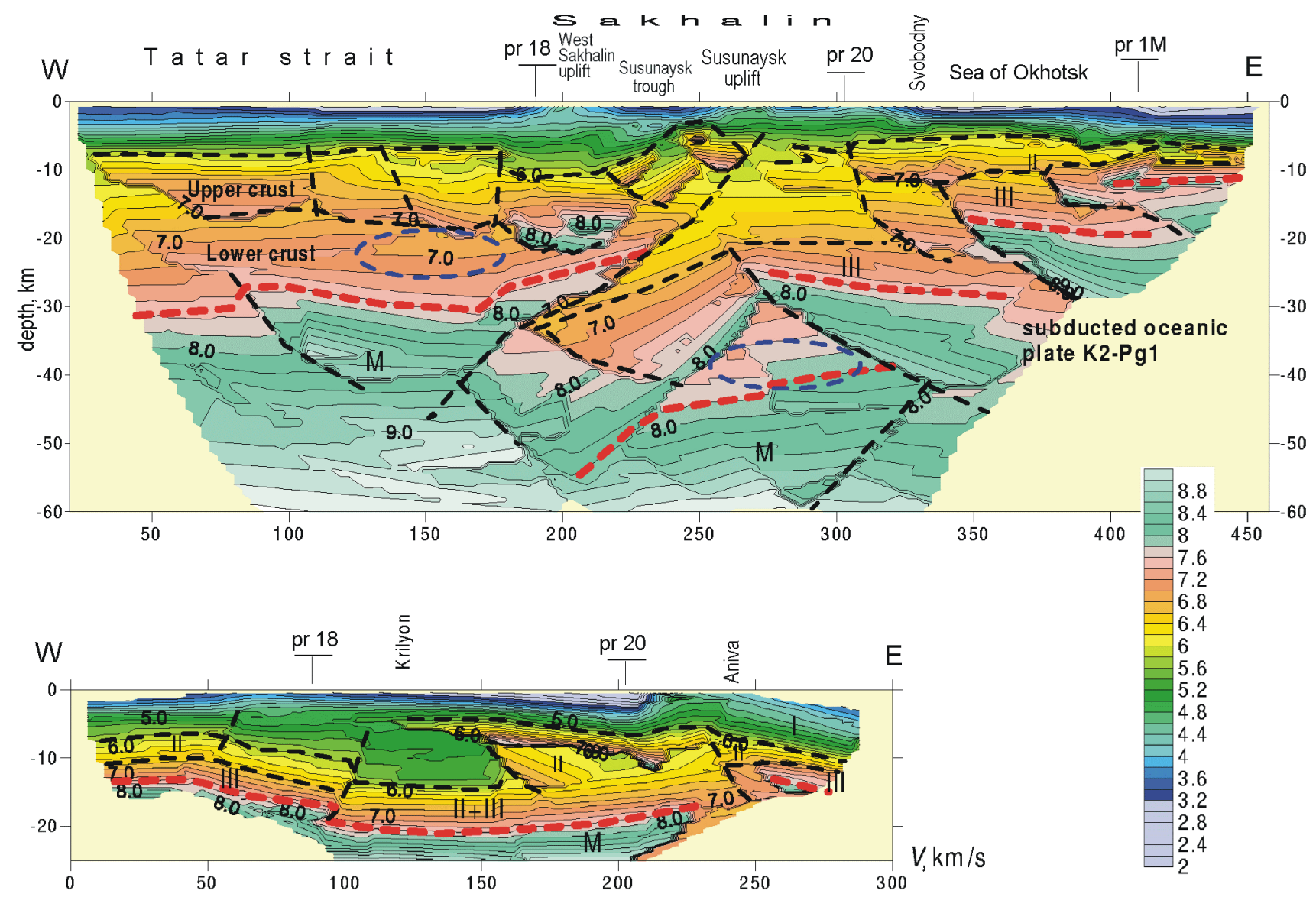

Figure 8. Seismic cross sections and geological interpretation along profiles 19 and 27 crossing southern Sakhalin in sublatitude direction. Most detailed system of observation was obtained along 19 profile. Here paleosubduction zone are traced most clearly. Oceanic plate by steps is dipped in upper mantle.

\section{Kuril Deep-Sea Basin}

Two parallel $1 \mathrm{M}-1 \mathrm{O}$ and $6 \mathrm{M}$ profiles cross the Kuril Basin (Figure 1) with a distance of roughly $200 \mathrm{~km}$ between them. The seismic sections along them are presented in Figure 9. The depth of the $M$ discontinuity in the Kuril Basin is 12 $15 \mathrm{~km}$. The $M$ surface showed velocities of 7.6 to $7.8 \mathrm{~km} \mathrm{~s}^{-1}$. The crust consists of three layers there. The sedimentary layer with a maximum thickness of $4 \mathrm{~km}$ showed velocities ranging from 2.0 to $5-6 \mathrm{~km} \mathrm{~s}^{-1}$. The thickness of the upper layer of the consolidated crust, varying from 6.0 to $6.8 \mathrm{~km} \mathrm{~s}^{-1}$ in seismic velocities, is 4 to $6 \mathrm{~km}$. The lower part of the crust with high seismic velocities $\left(7.0-7.6 \mathrm{~km} \mathrm{~s}^{-1}\right)$ varies greatly in thickness (4 to $10 \mathrm{~km}$ ) in the margins of the basin.

The western segments of the profile seem to have recorded the blocks of the subducted plate. They belong to a subduction zone near the eastern coast of Sakhalin. In this zone the oceanic crust of the Kuril Basin had been subducted under the continental crust of Sakhalin during late CretaceousEarly Paleogene time [Grannik, 1999].

Seismic section 19 (Figure 8) crossed the ophiolites, representing the remnants of some old subduction zone in South Sakhalin. The oceanic crust and mantle dip under Sakhalin to a depth of $50 \mathrm{~km}$. The oceanic plate dips roughly at an angle of $20^{\circ}$ in a depth range of $30-50 \mathrm{~km}$. The western segment profile 19 shows a thick continental crust and a mantle. The crust has been estimated roughly to be $35 \mathrm{~km}$ there. The structure based on the data of profile 19 has been verified by the seismic section recorded along meridional profile 20 (Figure 6).

Profile 20 (Figure 6) crossed the subduction zone near the Sakhalin coast along the strike of this zone. The main block of the subduction zone, located under the central segment of the profile, is broken by faults and seems to be composed of ophiolites which outcrop in the eastern part of Sakhalin. An accretionary prism is supposed to be located along the $290-330-\mathrm{km}$ segment of the profile. The subduction zone is distinguished by high seismic velocities and by high velocity 
กุ

के लं
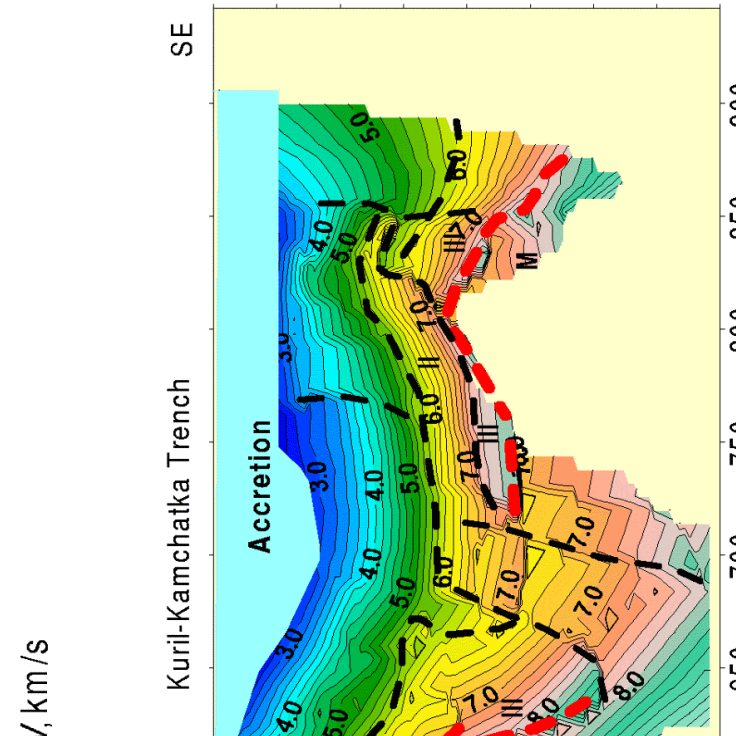

岗
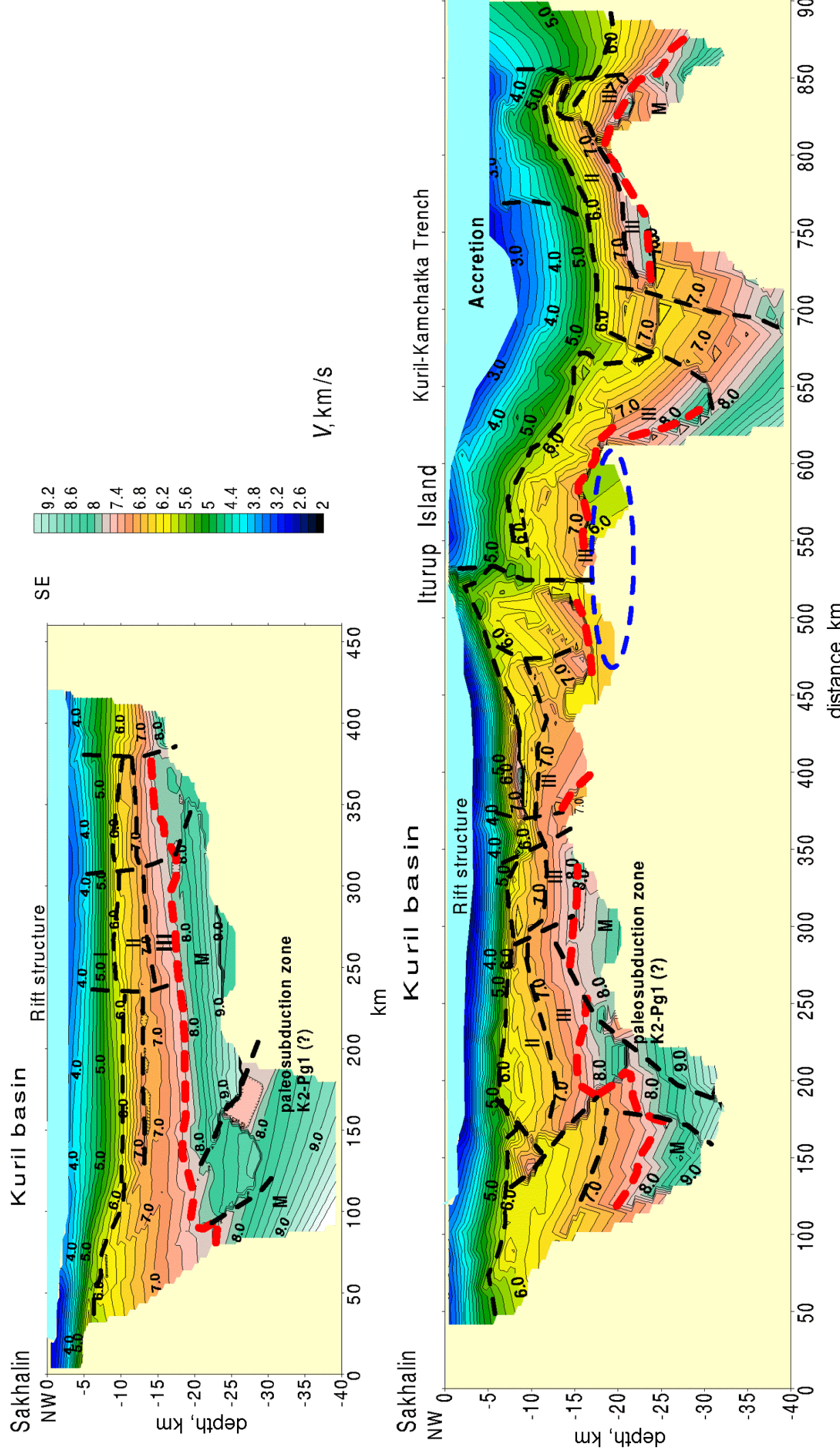

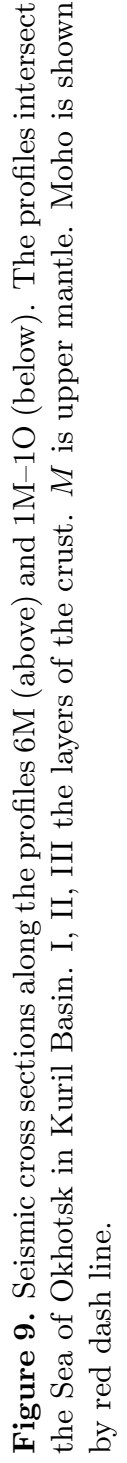




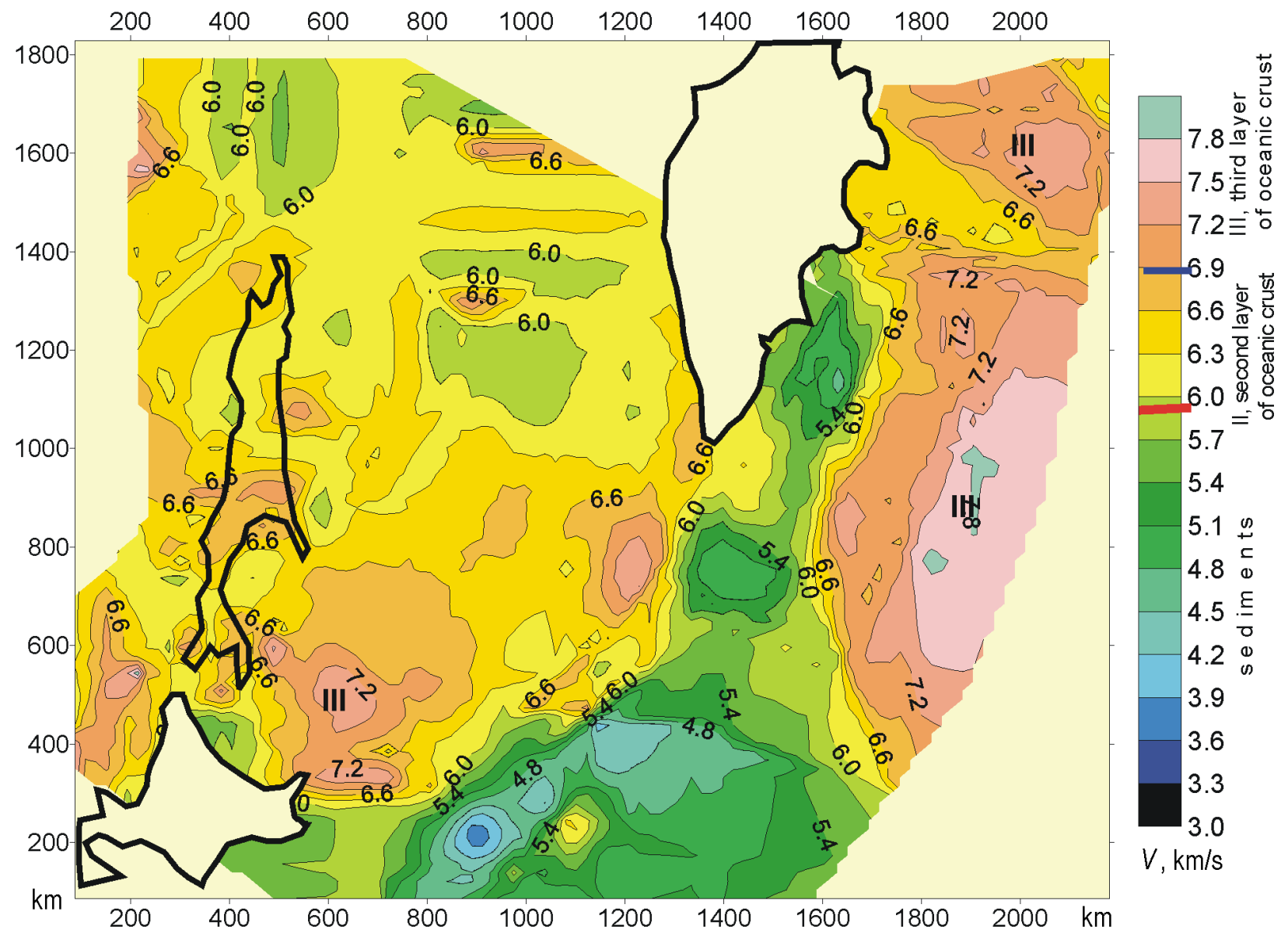

Figure 10. Velocity map-slice at the depth $12 \mathrm{~km}$. Thin black lines are velocity contours. Contour interval is $0.3 \mathrm{~km} \mathrm{~s}^{-1}$. Velocities corresponding to layers of oceanic crust and top of basement (red line) are marked in the color scale.

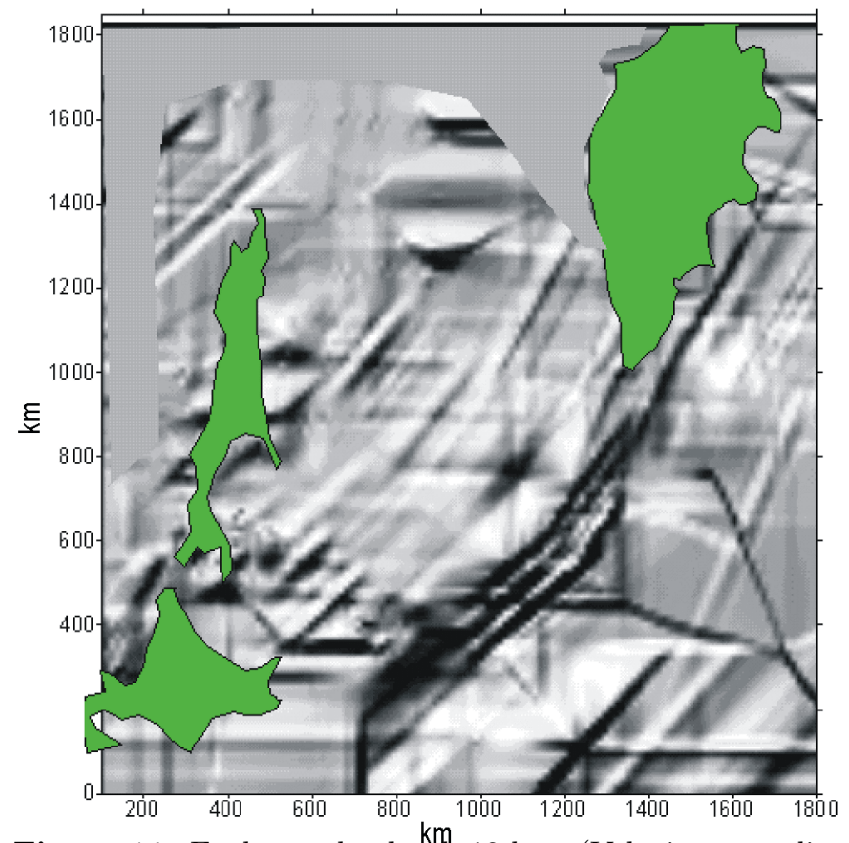

Figure 11. Faults at the depth $12 \mathrm{~km}$. (Velocity map-slice at the depth $12 \mathrm{~km}$ with the shadow relief). gradients. This structure of the subduction zone there was recorded confidently along five profiles $(19,20,27,1 \mathrm{M}$, and $6 \mathrm{M})$, where the position of the subduction zone coincides everywhere with the edge of the kuril basin. This can be seen in Figure 10 which shows a seismic velocity map for a depth of $12 \mathrm{~km}$.

A rift or spreading zone has been mapped in the central part of the Kuril Basin using the seismic data obtained along profiles $1 \mathrm{M}$ and $6 \mathrm{M}$. This structural feature has an excellent expression in the upper sedimentary layers. The faults responsible for its formation extend into the upper mantle, where the zones of abnormally low velocities $\left(7.0-7.5 \mathrm{~km} \mathrm{~s}^{-1}\right)$ are likely to mark an asthenospheric diapir including magma-formation chambers. The fact that the upper mantle under the Kuril Basin includes partial melting regions has been proved by electromagnetic measurements [Lyapishev et al., 1987]. These measurements located a layer with a specific conductivity of $0.3-0.5 \mathrm{~S} \mathrm{~m}^{-1}$ and an integral conductivity of about $15000 \mathrm{~S}$. The origin of this layer is believed to have been associated with partial melting, and its size is controlled by the size of the basin. Another highconductivity layer is believed to exist at a depth of $>100 \mathrm{~km}$. The results of this study agree with the upper mantle temperatures, as well as with seismic and other geophysical data 


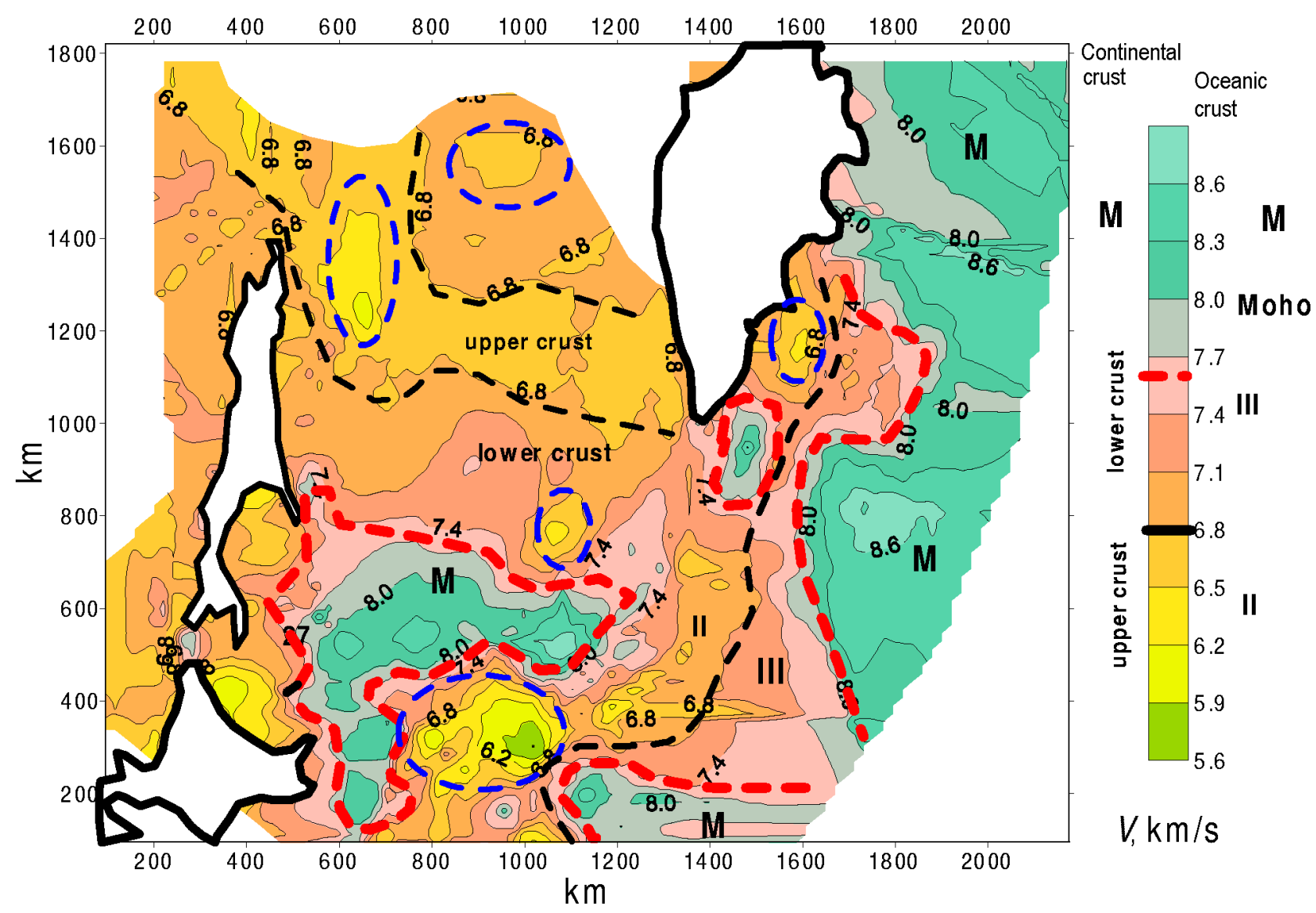

Figure 12. A velocity map-slice at depth of $20 \mathrm{~km}$. Thin lines are velocity contours. The Moho boundary is shown by a red dashed line, a top of a lower crust and top of third layer of ocean crust are given by a black dashed line. The dark blue dashed ovals show a position of plums.

[Maruyama et al., 1997]. This basin is known to show high heat values. The highest mantle temperatures, as high as $1200^{\circ}$, have been observed under the Kuril Basin at a depth of about $25 \mathrm{~km}$, marking a partial melting zone [Smirnov and Sugrobov, 1980]. Rifts and basic magmatism in the floor of the Kuril Basin mark the rises of the hot anomalous mantle.

\section{Horizontal Velocity Maps}

A horizontal velocity map is presented in Figure 10 for a depth of $12 \mathrm{~km}$. This map was plotted using the data provided by 25 profiles from the region discussed. Because the velocity contour lines are usually parallel to the seismic boundaries, the horizontal velocity maps reflect the positions of deep crustal structural features, the low-velocity areas showing the basins, and the high-velocity areas, the uplifts. The maps also show faults and folds.

The map presented in Figure 10 shows the structural features of the upper crust (Figure 10). These are the accretionary prism, the structural features of the third oceanic layer in the Pacific, and the positions of the subduction and rift zones in the Kuril Basin. This map also shows several blocks of the Pacific plate, separated by transform faults (Figure 10). The positions of these faults are known from the seismological and magnetic data available. One can see that the active subduction plate in the area of the Kuril Trench is broken into large segments with are turned clockwise relative to the trench axis. This suggests an oblique subduction.

Figure 11 shows a shadow of velocity map for a depth level of $12 \mathrm{~km}$. One can see that the main structural elements and faults in the Sea of Okhotsk region are expressed well in the velocity field and have a NE-SW strike similar to that of the Pacific structural features. The exception is the Deryugin Basin, bordering Sakhalin in the east, where the isometric structural features of the crust are preserved. Figure 12 shows a horizontal velocity map for a depth of $20 \mathrm{~km}$. The upper mantle is shown by a red broken line at this depth west of the trench and in the Kuril Basin. The down-going upper mantle in the Pacific region is broken into three large blocks. Under the Kuril Basin the sheared upper mantle has the form of an arc with a low-velocity region (a mantle plume) in the middle. The upper mantle showed low velocities in some other sedimentary basins, namely, in the 
Deryugin Basin and in the Tatar Strait trough. The lower continental crust underlies the Sea of Okhotsk in its northern and central parts, and the upper crust, in the north of the sea.

\section{Conclusion}

The Sea of Okhotsk lithosphere is broken into blocks, as proved by the horizontal variation of the geological and geophysical parameters of the crust. The blocks of different ranks are separated by crustal faults, rifts, fold-and-nappe systems, and subduction zones.

The new interpretation of the seismic data confirmed the earlier ideas of the reduced crustal thickness in the deep-sea basins of the Sea of Okhotsk, such as, the Kuril Basin, the Deryugin and Tinro basins, the sedimentary trough of the Tatar Strait, where the Moho surface showed low boundary velocities of seismic waves, not higher than $7.6-7.8 \mathrm{~km} \mathrm{~s}^{-1}$. It appears that the sedimentary basins of the Sea of Okhotsk reside above asthenospheric diapirs including magma chambers.

A system of rifts and spreading centers was mapped in the northern and central parts of the Sea of Okhotsk, in the Deryugin Basin, in the Tatar Strait, and in the Kuril Basin.

Paleosubduction zones that had been active during the late Cretaceous and Early Paleogene time and are marked by ophiolite belts at the present time have been traced in the earth crust near the eastern shores of Sakhalin.

Remnants of paleosubduction zones were mapped using seismic data in the Sea of Okhotsk along the OkhotskChukotka volcanic belt, which seem to be the fragments of a lithospheric plate that had been going down under the active continental margin in Mesozoic time.

\section{References}

Abramovich, I. I., S. D. Voznesenskii, and N. G. Mannafon, Geodynamic evolution and metallogeny of the Okhotsk-Kolyma segment of the Okhotsk-Chukotka volcanic belt, Pacific Geology, 20, (2), 3-12, 2001.
Galperin, E. I., and I. P. Kosminskaya (Eds.), The Crustal Structure of the Transition Region between Asia and the Pacific Ocean, 308 pp., Nauka, Moscow, 1964.

Grannik, V. M., Reconstruction of a zone of earthquake foci in the East Sakhalin volcanic paleoarc from the distribution of rare earth elements, Dokl. Akad. Nauk, 366, (1), 79-83, 1999.

Konstantinovskaya, E. A., Tectonics of the eastern margins of Asia: Structural evolution and geodynamic modeling, Proc. XXXIV Tectonic Conf., GEOS, pp. 304-307, 2001.

Krasnyi, L. I., Geology and structure of the Sea of Okhotsk region, Pacific Geology, 21, (2), 3-8, 2002.

Lyapishev, A. M., P. M. Sychev, and V. Yu. Semenov, The electric conductivity of the upper mantle in the Kuril Basin, Sea of Okhotsk, Pacific Geology, (4), 45-55, 1987.

Maruyama, S., Y. Isozaki, J. Kimura, and M. Terabayashi, Paleogeographic maps of the Japanese Islands: Plate tectonic synthesis from $750 \mathrm{Ma}$ to the present, The Island Arc, 6, (1), 11-20, 1997.

Piip, V. B., The local reconstruction of a seismic section from refraction data using homogeneous functions, Fizika Zemli, (10), 24-32, 1991.

Piip, V. B., Deep seismic refraction sections of Sakhalin (Russia) based on data reinterpretation using a 2-D inversion method, Proc. 30th International Congress, 20, 11-20, 1997.

Piip, V. B., 2-D inversion of refraction traveltime curves using homogeneous functions, Geophysical Prospecting, 49, 461-482, 2001.

Rodnikov, A. G., N. A. Sergeyeva, and L. P. Zabarinskaya, Deep crustal structure of sedimentary basins in the transition zone from Asia to the Pacific Ocean, in Geophysics of the XXI Century, pp. 102-111, GEON, "Nauchnyi Mir", 2001a.

Rodnikov, A. G., N. A. Sergeyeva, and L. P. Zabarinskaya, Deep structure of the Eurasia-Pacific transition zone, Russian Journal of Earth Sciences, 3, (4), 293-310, 2001b.

Rodnikov, A. G., I. K. Tuezov, and V. V. Kharakhinov (Eds.), The Structure and Dynamics of the Lithosphere and Asthenosphere in the Sea of Okhotsk Region, 338 pp., National Geophysical Committee, Moscow, 1996.

Smirnov, Ya. B., and V. M. Sugrobov, The heat flow of the Earth in the Kuril-Kamchatka and Aleutian provinces, Volcanology and Seismology, (2), 3-17, 1980.

Zverev, S. M., and Yu. V. Tulina (Eds.), The Deep Seismic Sounding of the Earth Crust in the Sakhalin-Hokkaido Sea Zone, 286 pp., Nauka, Moscow, 1971.

Vorobjovy Gory, Moscow State University, 119922 Moscow, Russia, piip@list.ru

Geophysical Center, Russian Academy of Sciences, Moscow, 3 Molodezhnaya Str., 117296, Moscow, Russia, rodnikov@wdcb.ru

(Received 13 January 2004) 